\title{
Mineral investment and the regulation of the environment in developing countries: lessons from Ghana
}

\author{
Kyla Tienhaara
}

Received: 28 February 2006/ Accepted: 25 August 2006/

Published online: 4 October 2006

(C) Springer Science+Business Media B.V. 2006

\begin{abstract}
This article examines the relationship between foreign direct investment in the mineral sector and environmental regulation in developing countries. It argues that two major trends in global mineral investment have emerged in recent years: increased competition amongst developing countries to attract mineral investment, and the development and proliferation of a standard set of legal protections for mineral investors including access to international arbitration, prohibitions of expropriation without compensation, and commitments to stability of the regulatory regime. Both of these trends may have implications for environmental policy, which are examined in the paper both in general terms and in the context of a detailed case study concerning mineral exploitation in Ghana's forest reserves.
\end{abstract}

Keywords Developing countries $\cdot$ Environmental regulation $\cdot$ Foreign direct investment $\cdot$ Ghana $\cdot$ International arbitration $\cdot$ Mining

$\begin{array}{ll}\text { Abbreviations } & \\ \text { BIT } & \text { Bilateral Investment Treaty } \\ \text { FOE } & \text { Friends of the Earth } \\ \text { FDI } & \text { Foreign Direct Investment } \\ \text { ICSID } & \text { International Centre for the Settlement of Investment Disputes } \\ \text { NAFTA } & \text { North American Free Trade Agreement } \\ \text { OECD } & \text { Organisation for Economic Cooperation and Development } \\ \text { UNCITRAL } & \text { United Nations Commission on International Trade Law } \\ \text { UNCTAD } & \text { United Nations Conference on Trade and Development }\end{array}$

K. Tienhaara $(\bowtie)$

Environmental Policy Analysis, Institute for Environmental Studies, Vrije Universiteit Amsterdam, De Boelelaan 1087, Amsterdam 1081 HV, The Netherlands e-mail: kyla.tienhaara@ivm.falw.vu.nl 


\section{Introduction}

Global flows of foreign direct investment (FDI), including mineral ${ }^{1}$ investment, are overwhelmingly concentrated amongst Organisation for Economic Cooperation and Development (OECD) countries. However, for some developing countries, their small share of the global flows of mineral investment can represent a considerable share of overall FDI entering the country, and can contribute significantly to state revenue (Sandbroke \& Mehta, 2002, p. 2). At the same time it is also the case that "[f]ew if any forms of economic development present the array of potential environmental, social and economic problems of the mineral resources industry" (Pring \& Siegele, 2005, p. 129). There is no comprehensive international agreement on mining (Dalupan, 2005, p. 153) and environmental regulation for the sector in many developing countries is a relatively recent phenomenon (UNCTAD, 1997, p. 47). Furthermore, governments often lack the relevant tools and manpower to properly enforce the environmental regulations that are in place (Onwuekwe, 2006, p. 121). As Cohen (1996, p. 151) points out, "[w]ithout effective environmental controls, developing countries risk suffering serious, irreversible environmental harm" from large-scale mining projects. Thus the mining sector provides a good case study for the analysis of the relationship between investment and the environment in view of the environmental, economic and social importance of the sector in many FDI-host countries (Chudnovsky \& López, 2002, p. 62; Sandbroke \& Mehta, 2002, p. 2).

Against this backdrop, there are two important (and interrelated) trends occurring in mineral investment, which reflect broader developments in international investment generally: first, the increased competition amongst developing countries to attract foreign investors; and second, the development and proliferation of a standard set of legal protections for those investors. The purpose of this paper is to provide a brief overview of these two trends, with a particular focus on how they may affect the regulation of the environment in developing countries, and also to further explore these issues within the context of a detailed case study concerning mineral exploitation in Ghana's forest reserves. While both competition for investment and the legal protection of investment are subjects of intense academic debate, which has included discussion of environmental issues (e.g. the pollution haven hypothesis, see Sect. 2; and the legal discussion surrounding investor-state disputes, see Sect. 3) these topics are rarely treated together. As a result the links between the two trends are often not drawn. Furthermore, while research on competition has been dominated by economic/statistical analyses and legal discussions have been concentrated on a few disputes (mainly within the context of the North American Free Trade Agreement/NAFTA ${ }^{2}$ ), few authors have provided detailed case studies from the developing world. The paper concludes with some lessons that can be drawn from the Ghanaian case, as well as suggestions for further research.

\footnotetext{
${ }^{1}$ As Otto and Cordes (2002, p. II-3) correctly point out, the term 'minerals' can cover a wide range of substances. In this paper, the term refers to metallic or industrial minerals (nickel, silver, gold etc.) and excludes energy related minerals (petroleum, gas, coal) and radioactive minerals, which are generally regulated by separate and specialised policies.

${ }^{2}$ Chapter 11 of the Agreement covers investment. See http://www.nafta-sec-alena.org.

型 Springer
} 


\section{State competition for mineral investment}

According to Oman (2000, p. 15), "[c]ompetition among governments to attract corporate investment appears to have heated up in recent years". The reasons postulated for this include: the large number of developing/transitional countries that have moved from closed to market friendly economies in the 1980s/90s; the fact that OECD governments have also moved to more deregulated and liberalised economies and are seeking to attract more investment; the increased mobility of capital; and the reduction in barriers to international investment (Oman, 2000, pp. 15-16).

This competition is particularly evident in the minerals sector. The debt crisis, combined with the deterioration in developing countries' terms of trade led to a global movement away from State control of the mineral sector, which began in the late 1970s and gained momentum in the 1980s and 1990s (UNCTAD, 1997, p. 6). Structural Adjustment Programmes developed by the World Bank/International Monetary Fund also played an important role in driving this process. As Otto (1994, p. 2) points out, the result is that mining companies have "unprecedented access to a vastly increased portion of the planet's land area". Thus,

at the turn of the millennium, international investors faced an increasing number and variety of geologically interesting countries with acceptable legal and fiscal frameworks. Consequently, countries have had to compete among one another to attract investment into their minerals sectors on a continuing basis (Williams, 2005, p. 38).

While mineral investors remain fundamentally 'resource-seeking' (Caspary \& Berghaus, 2004, p. 684), competition within a set of geologically favourable countries will be based on other factors. As Omalu and Wälde (1998) state: "any country with a favourable geology has to combine this with an attractive mineral investment regime to attract considerable mineral sector investment". Otto and Cordes (2002, p. III-3) found that around 120 countries have reformed their legal regimes for mining since 1985 .

With regard to the impact of state competition for foreign investment on the environment, academic discussion has long been dominated by the debate surrounding the 'pollution haven' hypothesis. This hypothesis relates to the notion that investors will be attracted to countries with lower 'environmental costs', and that in order to be competitive countries will attempt to keep such costs low;

A country provides a pollution haven if it sets its environmental standards below the socially efficient level or fails to enforce its standards in order to attract foreign investment from countries with higher standards or countries that better enforce their standards (Neumayer, 2001a, p. 148).

Two closely related concepts are 'industrial flight' and the 'race to the bottom', which Mabey and McNally (1999, p. 30) effectively combine into a comprehensive definition of the whole phenomenon:

in order to attract investment, governments will undervalue their environment through law or non-enforced regulation (the "pollution havens" hypothesis). As a result, companies will shift operations to these countries to take advantage of lower production costs (the "industrial flight" hypothesis). Both lead to 
excessive (sub-optimal) pollution in the host country and a potential race-tothe-bottom in environmental standards.

Although it would be logical to assume that the pollution haven hypothesis emerged out of a concern about the potential impacts that foreign investment could have on environmental quality in developing countries, in fact, it was rather the threat of industrial flight and concerns over potential job losses that first sparked an interest in developed/OECD countries (Clapp, 2002, p. 11; Mabey \& McNally, 1999, p. 30; Oman, 2000, p. 92; Strohm, 2002, p. 29). As a result, many of the early studies on pollution havens were actually pre-occupied with this one aspect of the overall phenomenon. By the mid-1980s, researchers had concluded that the new strict environmental regulations in developed countries had not caused industrial flight, and thus rejected the validity of the pollution haven hypothesis as a whole (Strohm, 2002, p. 31).

However, despite the lack of evidence about industrial flight, public concern about pollution havens did not dissipate. Furthermore, many researchers themselves did not appear to be completely convinced. As Wheeler (2002, p. 6) notes, despite the lack of evidence "caution is undoubtedly warranted because there is no theoretical reason why industries with exceptionally high pollution control costs should ignore regulatory concerns". An opponent of the hypothesis would likely argue in response that because environmental costs make up only a small proportion of a company's total costs, they will have little impact on a firms' locational decisions, particularly in comparison to other factors, which Oman $(2000$, p. 17) refers to as "fundamentals" (political and macroeconomic stability, market access, infrastructure etc.). However, it is also true that, particularly in certain industries, environmental costs are on the rise, while at the same time industrial relocation is becoming easier "[w]ith fewer barriers to foreign investments, easier repatriation of profits and other commitments facilitating trade and capital flows" (Esty \& Geradin, 1998, p. 9). In the mineral sector, it is widely acknowledged that it "has become increasingly more difficult to mine in most developed nations" (Otto \& Cordes, 2002, p. III-3), due in large part to ever more stringent environmental regulations.

Recently, researchers have found "statistically significant pollution haven effects of reasonable magnitude" (Brunnermeier \& Levinson, 2004, p. 38), and the earlier consensus about pollution havens may be changing. In addition, there has been an increasing amount of academic critique of the entire framing of pollution haven research. Of particular relevance to this paper is the criticism that the scope of the problem is narrowly confined by the definition of 'dirty industry' adopted by most researchers who investigate pollution havens. The primary focus has been on the manufacturing sector, ignoring the highly polluting resource extraction industries, which make up the bulk of investment flowing to many lowincome countries (Clapp, 2002, p. 12; Mabey \& McNally, 1999, p. 11). Neumayer (2001a, p. 173) notes:

Especially in the mining and other resource extraction sectors, multinational corporations also at times do take advantage of low environmental standards in the host country - an impact on the environment that is outside the pollution haven hypothesis proper.

Environmental damage is also very narrowly defined in pollution haven research. The data used to determine which sectors are highly polluting is largely emissions data or information on expenditures related to emissions controls (Clapp, 2002, 
p. 12). Habitat destruction, biodiversity loss, and numerous other environmental impacts are not captured by this limited scope. In the case of mineral production, "upstream problems (land and ecosystem degradation, acid mine drainage, slope failures, etc.)" are the predominate concerns, particularly in the case of open-pit or surface mining (Warhurst, 1994, p. 42).

\section{Mabey and McNally (1999, p. 3) argue that}

By asking the wrong question, and looking for the wrong evidence the "pollution havens" debate has deflected discussion away from more important issues such as: the scale of economic activity relative to regulatory capacity and environmental limits; broad development/environment linkages; resource use and planning issues, and the complex policy and institutional failures linked to competition for FDI both between and inside regional trading areas.

Many researchers appear to agree, and now advocate the abandonment of the pollution haven debate and the adoption of a "more open-ended analysis of the linkages between global trade and investment and environmental regulation" (Clapp, 2002, p. 12). In dismissing the value of continued research on pollution havens, several authors have directed attention to a potential new avenue for research on the relationship between investment and the environment. Neumayer (2001b, pp. 20-21) argues that "what really matters is what policy makers believe, not what economic theory and evidence says, and there can be no doubt that they actually do believe that countries compete with each other" (emphasis added). The notion that regulators fear raising environmental standards beyond the status quo because they believe it may deter new investment or cause industrial flight has been termed 'regulatory chill'.

Regulatory chill is not restricted to an investor's decision on where to locate, as it is also acknowledged that established companies may apply pressure to host governments to lower, not raise, or not enforce environmental regulations (Mabey \& McNally, 1999, p. 42). Furthermore, this new research paradigm broadens the scope of environmental degradation beyond traditional notions of 'pollution'. In doing so, it also broadens the scope from purely local/national issues, to environmental issues of global concern. In fact Neumayer (2001b, p. 3) suggests that:

A priori, we would expect 'regulatory chill' to be more prevalent with respect to environmental standards concerning pollutants affecting the so-called global commons, such as the global climate, the ozone layer, and biodiversity...because in the case of the global commons, the benefits of raising environmental standards have to be shared with all or at least many other countries as well. In as far as capital flight is perceived to be one of the costs of raising environmental standards, it will become relatively more important in this case then, as the costs are balanced against dispersed benefits.

The method of enquiry proposed for evaluating regulatory chill is also in marked contrast to that adopted for pollution haven research. Statistical analysis is difficult, if not impossible, when one is looking for evidence of "what has not happened" (Mabey \& McNally, 1999, p. 40). Thus, it is argued that the research should be conducted by historians and political scientists, not economists, and should involve detailed case analysis (Clapp, 2002, p. 17; Mabey \& McNally, 1999, p. 40). 


\section{State commitments to investment protection}

Closely linked to the increased competition amongst developing countries to attract foreign investment is the trend of countries to offer certain forms of legal protection to investors. These legal protections are aimed at managing 'political risk' which

can be understood as the occurrence of events in the political sphere (governmental actions, politically motivated insecurity in the country and international conflict) which impede the normal operations of a business venture with a detrimental financial impact on the commercial viability of the venture (Wälde \& N'Di, 1996).

Such risk is inherent to all investment, but is perceived as particularly strong for investments in developing countries, and also for those in the mineral sector, which are seen as particularly vulnerable because they:

1) are highly capital-intensive investments that cannot be relocated;2) use relatively stable production technologies; 3) produce a homogeneous product with little customer or brand name loyalty; and 4) operate in an oligopolist industrial structure with limited competitors (Otto \& Cordes, 2002, p. I-41)

Investment protection can be found in national laws, bilateral investment treaties (BITs) (now numbered at over $2300^{3}$ ), as well as in numerous regional treaties, ${ }^{4}$ and many 'state contracts'.

\subsection{Bilateral investment treaties}

BITs are agreements between two countries that concern the relationship between an investor from one party, referred to as the 'home state', and the other contracting party, the 'host state'. While BITs work both ways (with each state able to act as a 'home' and 'host' to investors) they have generally been designed by the industrialised world with the interest of Western investors in mind. The first BITs were created to deal with the period of uncertainty following colonisation, and the main purpose of BITs today is still to protect foreign investors in the developing world. While an increasing number of BITs are now negotiated between developing countries, there is a dearth of such agreements between industrialised nations (Hallward-Driemeier, 2003, p. 8).

Though many BITs follow a similar pattern, there are differences among them based on which countries were involved in the negotiation, and when they were concluded. For example, BITs negotiated by the United States differ in certain ways from those negotiated by most European countries, and early BITs are generally less stringent and more vague than more recent treaties (Sornarajah, 2004, p. 216). While there are several clauses common to BITs that are potentially relevant to environmental protection, two of the most contentious ${ }^{5}$ and most relevant to the mineral

\footnotetext{
${ }^{3}$ The United Nations Conference on Trade and Development (UNCTAD 2005d, p. 2) counted 2393 BITs, up to and including those concluded in 2004.

${ }^{4} \mathrm{UNCTAD}$ maintains a compendium of international investment agreements, available online at: http://www.unctad.org.

${ }^{5}$ See Sornarajah (in this issue) for a discussion of other clauses, such as fair and equitable treatment, which are increasingly relevant.
}

算 Springer 
sector are access to international arbitration and prohibitions of expropriation without compensation.

\subsubsection{International arbitration}

A state-to-state dispute settlement mechanism is present in the large majority of international investment agreements. Arbitration provides an option beyond diplomatic negotiations, but formal state-to-state investment disputes tend to be quite rare (Peterson, 2005, p. 127). In the 1960s a second type of dispute settlement mechanism began to appear, which allowed for arbitration between an investor and the host state. There are two types of investor-state dispute settlement: 'institutional' and 'ad hoc'.

Institutional dispute settlement involves a supervising institution that administers the arbitration. The most common institution referred to in international investment agreements is the International Centre for the Settlement of Investment Disputes (ICSID). ICSID is a part of the World Bank Group and was established in 1966 when the Convention on the Settlement of Investment Disputes between States and Nationals of Other States came into force. Its most recent set of Rules and Regulations entered into force in 2006. ${ }^{6}$ ICSID was designed expressly for the purpose of handling investor-state arbitrations and does not handle disputes between firms.

Ad hoc arbitrations also follow sets of established rules; however, in these cases there is no supervising institution. The most common ad hoc rules referred to in international investment agreements and state contracts are those of the United Nations Commission on International Trade Law (UNCITRAL). UNCITRAL was established by the UN General Assembly in 1966 and was given the general mandate to further the progressive harmonisation and unification of the law of international trade. ${ }^{7}$ An integral part of the Commission's work is the promotion of the Convention on the Recognition and Enforcement of Foreign Arbitral Awards (1958 'New York Convention'). The UNCITRAL Arbitration Rules were adopted in $1976^{8}$

Investment treaties rarely require that foreign investors first exhaust domestic legal remedies before proceeding to international arbitration, in contrast with other international legal mechanisms. ${ }^{9}$ Foreign investors and advocates of international arbitration argue that local courts in developing countries are ill equipped to deal with investment disputes and, furthermore, that if asked to adjudicate claims brought against their own State these courts "may hardly be able to resist the political pressure inherent in this situation" (Bernardini, 2001, p. 246). International arbitration, to the contrary, is commonly framed in the literature as neutral and depoliticised. However, in recent years, an increasing number of observers have disparaged international arbitration for its lack of transparency, accountability, and

\footnotetext{
${ }^{6}$ The Rules and Regulations are available online at http://www.worldbank.org/icsid/.

${ }^{7}$ See the UNCITRAL website at: http://www.uncitral.org/uncitral/en/index.html, last viewed 06-0706.

${ }^{8}$ The full text of the Rules is available online at: http://www.uncitral.org/uncitral/en/uncitral_texts/ arbitration/1976Arbitration_rules.html.

${ }^{9}$ For example the European Convention on Human Rights requires claimants to begin in local courts.
} 
openness to third-party participants. ${ }^{10}$ Furthermore, it has been argued that international arbitration may particularly disadvantage developing countries, due to the high costs of disputes, ${ }^{11}$ their lack of expertise and experience in dealing with arbitration, and structural biases within the system. ${ }^{12}$

A plethora of investor-state disputes have sprung up in the last decade. The cumulative number of all known ${ }^{13}$ cases brought under investment agreements was 219 as of November 2005, excluding instances where a notice of intent had been filed but the request for arbitration had not (UNCTAD, 2005c, p. 2). This can be compared to the end of 1994 when there were only 5 known cases. At least 61 governments (37 in the developing world) have faced investment arbitration (UNCTAD, 2005c, p. 3).

Concerns have been raised in the wake of several controversial investor-state disputes, ${ }^{14}$ particularly within the context of NAFTA, that in some instances the protection offered to investors may limit the ability of governments to regulate investment for the protection of the environment, natural resources and other social goods, and further that investor-state arbitration may not be an appropriate venue for issues of public concern to be decided upon. ${ }^{15}$ Some authors have also hypothesised that the threat of an investor-state dispute could have a chilling effect on government policy (Gray, 2002, p. 311; Moltke \& Mann, 2004, p. 30; Neumayer, 2001a, p. 87).

\subsubsection{Expropriation}

In the past, particularly in the 1960s and 1970s, the direct taking of foreign property was one of the most significant risks to foreign investment, and usually came in the form of what is termed 'nationalisation'. Nationalisation of foreign property involves the host government performing an outright taking of property in all economic sectors or on an industry-specific basis. In contrast to nationalisation, 'expropriation'

\footnotetext{
${ }^{10}$ See generally: Blackaby (2004), Garcia (2004), and Peterson (2005).

${ }^{11}$ According to an UNCTAD (2005b) report, companies have been known to spend up to US\$4 million on lawyers' and arbitrators' fees for an investor-state dispute, and countries can expect an average tribunal to cost US $\$ 400,000$ or more in addition to the US\$1-2 million in legal fees.

${ }^{12}$ For a developing country perspective on investment arbitration see: Garcia (2004), and Sornarajah (2002).

${ }^{13}$ Cases are not necessarily made public, and thus it is not possible to assess how many exist in total.

${ }^{14}$ See for example Compania del Desarrollo de Santa Elena SA v. Republic of Costa Rica (2000) International Legal Materials 39(6), 1317-1337 (award available online at: http://www.worldbank.org/ icsid/cases/awards.htm), Ethyl Corp. v. Government of Canada. 1999. International Legal Materials 38(3), 700-737 (award available online at: http://www.dfaitmaeci. gc.ca/tna-nac/disp/ethyl_archiveen.asp), Glamis Gold Ltd. v. United States of America (case pending, preliminary documents available online at http://www.state.gov/s/l/c10986.htm), Metalclad Corp. v. United Mexican States. 2001. ICSID Review 16(1), 165-202 (award available online at: http://www.worldbank.org/icsid/cases/ awards.htm), Methanex Corp. v. United States of America. 2005 (award available online at http:// www.state.gov/s/1/c5818.htm), S.D. Myers, Inc. v. Government of Canada. 2001. International Legal Materials 40(6), 1408-1492 (award available online at: http://www.dfait-maeci.gc.ca/tna-nac/disp/ SDM_archive-en.asp), Técnicas Medioambientales Tecmed, S.A. v. United Mexican States (ICSID Case No. ARB(AF)/00/2) (award available online at: http://www.worldbank.org/icsid/cases/ awards.htm).

${ }^{15}$ See for example Baughen (2001), Gantz (2001), Guzman (1998), Mann (2001), and Peterson (2003).
} 
involves takings targeted at specific properties and enterprises (many agreements, however, refer to both nationalisation and expropriation as simply 'expropriation').

Outright takings are now considered rare in most parts of the world. However, another form of taking, referred to as 'indirect takings' or 'indirect expropriation', has become increasingly important. Indirect takings fall short of actual physical taking of property, but result in the effective loss of management, use or control, or a significant depreciation of the value of the assets of a foreign investor (UNCTAD, 2000 , p. 4). Indirect takings can be further divided into 'creeping expropriations' and 'regulatory takings'. Creeping expropriations involve the slow and incremental encroachment on the ownership rights of a foreign investor, leading to the devaluation of the investment. Regulatory takings are "those takings of property that fall within the police powers of a State, or otherwise arise from State measures like those pertaining to the regulation of the environment, health, morals, culture or economy of a host country" (UNCTAD, 2000, p. 12).

The issue of regulatory takings is a particular point of concern from the perspective of environmental protection, as well as other sensitive areas of public policy. There is no comprehensive definition of what constitutes a regulatory taking with many tribunals and academics suggesting "that a determination as to the occurrence of an expropriation can only truly be undertaken on a case-by-case basis, in light of all attending circumstances" (Fortier \& Drymer, 2004, p. 314). Soloway (2002, p. 31) explains the difficulty of developing a definition:

If the definition is too expansive, the argument goes, it could impose potentially huge financial obligations on governments, create disincentives to enact health and safety regulations, and introduce multiple distortions and social inefficiencies. On the other hand, a definition that is too restrictive would obliterate a key investment guarantee that protects foreign investors.

The "huge financial obligations" that could be imposed on governments relate to not only the legal costs associated with defending a regulation in international arbitration, which can be significant, but also to the potential compensation payments that can be awarded to the investor if a tribunal determines that an expropriation has occurred. $^{16}$

\subsection{National mineral policy and state contracts}

In addition to any general commitments to investment protection made by a state under international agreements with other states, there may also be specific protections offered to mineral investors under national law or through contracts made directly with investors.

According to de Sa (2005, p. 493), the "building blocks" of a successful mineral policy are: a transparent legal and regulatory framework; a competitive, stable and fair fiscal regime; strong institutions to implement them; and sound environmental management systems. In addition, the mineral policy must be combined with broader economic reforms, which includes "the establishment of a competitive investment climate for private sector participation, including the liberalisation of

\footnotetext{
${ }^{16}$ For example, Ethyl Corp. sought $\$ 251$ million from Canada, Metalclad Corp. sought \$90 million from Mexico, and Methanex sought a staggering $\$ 970$ million from the United States. The actual compensation awarded in a case is, however, usually lower than that sought by the claimant.
} 
investment laws, and deregulation" (de Sa, 2005, p. 495). Bastida (2001, p. 32) also highlights that a key legal protection for many mineral investors is security of mineral tenure;

At its most elementary, security of tenure implies the notion that the investor has to be provided with the assurance of being able to develop a successful discovery prior to committing sizeable resources to exploration, or the right to proceed from the exploration to the mining stage ('the right to mine'). However, in recent years the understanding of the concept has tended to broaden, both to take account of the uncertainties involved in carrying out a mining project, and the need to do it profitably.

In most developed countries mining rights are based only on law and regulation, however developing countries have relied far more on agreements with investors referred to as 'state contracts' (and sometimes as 'concession agreements' in the area of natural resource exploitation) (UNCTAD, 1997, p. 9, 2004, p. 3). A state contract can be defined as

a contract made between the State, or an entity of the State, which, for present purposes, may be defined as any organization created by statute within a State that is given control over an economic activity, and a foreign national or legal person of foreign nationality (UNCTAD, 2004, p. 3).

Prior to the beginning of the decolonisation process, the concession contract was the main form of agreement between a foreign mining investor and a national government in the developing world. At that time, mining companies possessed greater bargaining power as they had the support of their home states. Following decolonisation, in the period defined by the move by developing countries to assert sovereignty over natural resources, the bargaining power shifted, and many mining contracts were renegotiated or the industries were nationalised. In recent years, with the increased competition between states for mineral investment, Barberis (1998, p. 3) argues that the bargaining power has begun shifting back in favour of mining companies.

Despite the fact that mining companies may currently be said to have the advantage in negotiating contracts, it is also the case that these contracts can be seen as an 'obsolescing bargain' (Barberis, 1998, p. 54). This means that the power of the foreign investor wanes dramatically over the period of the contract, as investment is sunk into a project (Wälde \& N'Di, 1996). Thus investors are concerned that governments may exploit their improved position and try to alter the terms of the initial agreement. It is this risk that has motivated the move towards the internationalisation' of state contracts:

The theory of internationalization of contracts suggests...that the obligations arising from a contract may reside in an external system. This external system is variously described as transnational law of business, general principles of law, lex mercatoria and even as international law. This theory states that the use of certain clauses may have the effect of internationalizing the contract for certain purposes, at least those connected with termination and dispute resolution (UNCTAD, 2004, p. 6). 
State contracts often contain arbitration clauses referring to the dispute settlement mechanisms already discussed in the previous section. There are also other protections, however, which are not generally found in international agreements. Particularly in the mineral sector, the high level of risk inherent in the activity, as well as the scope and size of resources required has "led to the establishment by the large multinational companies of a particularly refined system of contractual guarantees for the protection of their investments" (Bernardini, 2001, p. 236). This paper will focus on the guarantee of stability.

\subsubsection{Stability}

According to Pritchard (2005, p. 80), "adverse change in law" (that is any change in law which may adversely affect an investment) is the "most feared legal risk of mining investors". One method of managing the risk of adverse change in law is the use, in national law or state contracts, of stabilisation clauses, which "seek to preserve the law of the host country as it applies to the investment at the time the state contract is concluded, and which ensures that the future changes to the law of the host country are inapplicable to the foreign investment contract" (UNCTAD, 2004, p. 26). Stabilisation clauses were reported to have diminished in scope and frequency in the 1970s, but they now appear to be re-emerging in even more extensive forms than were previously observed (Wälde \& N'Di, 1996). This is particularly the case in the resource extraction sector, where according to many authors, investments have a greater need for stability than other shorter-termed industrial projects (Bernardini, 2001, p. 236; Wälde \& N'Di, 1996).

While stability of the fiscal regime is of primary interest to investors, there are other issues for which it may be desirable to negotiate a stabilisation clause:

Perhaps most relevant at the moment is the imposition of new environmental obligations by subsequent regulation or by an administrative/judicial ruling re-interpreting existing law on which, arguably, the investment decision may to some extent have been based (Wälde \& N'Di, 1996).

As Verhoosel (1998, p. 457) points out, even if a stabilisation clause does not explicitly refer to environmental regulation it could effectively cover it. For example, a stabilisation of the fiscal regime could cover market-based environmental measures. However, while advantageous to the investor, such clauses may be problematic from the perspective of the regulator:

Environmental management is a dynamic activity, responding to growing knowledge concerning the environment and anthropogenic threats to it, as well as to changing perceptions concerning the seriousness of these threats... An added level of complexity derives from the continuous development of technologies designed to protect the environment. As these technologies become available, policy must adjust to reflect new capabilities (Moltke, 2002, p. 358).

Applying the constraints of stability to the regulation of the environment, particularly in the developing world, is thus a subject of legitimate concern.

Some authors have questioned the binding character of stabilisation clauses, arguing that states cannot waive their sovereignty in such a manner 
(Bernardini, 2001, p. 242; Sornarajah, 2004, p. 408). However, despite the academic debate, the crucial point is that tribunals have frequently affirmed the validity of such clauses (Verhoosel, 1998, p. 456). Most observers would agree with Peter (1995, p. 227) who argues that while stabilisation clauses cannot stop a government from "doing what it pleases", the investor will be entitled to "comprehensive compensation" in the instance of a breach.

In light of the problems associated with stabilisation clauses, many contracts adopt a slightly less demanding alternative; the renegotiation clause:

By undertaking to renegotiate the contractual terms and conditions in case of supervening circumstances of any kind, including new legislative or regulatory measures, the State binds itself to conduct good faith negotiations with the private investor with the view of maintaining the economic equilibrium of the agreement as originally stipulated. An essential component of this type of provision is the granting to the international arbitrator of the power to determine the new economic equilibrium of the agreement should the parties fail to find an agreement in this regard within a specified time-limit (Bernardini, 2001, p. 242).

As with a breach of a stabilisation clause, renegotiation may result in compensation requirements or other remedies to restore the 'economic equilibrium' of the contract.

\section{Case study: mining in Ghana's forest reserves}

In the previous sections it has been argued that developing countries are increasingly driven to compete with each other to attract mineral investment and that as a consequence they have made fairly substantial commitments to provide investors with stability, protection from expropriation without compensation, and access to international arbitration in the event of a dispute. There is considerable debate as to the precise effect of these clauses; however in any event, as Otto and Cordes (2002, p. IV-26) point out, "their effect may be more a psychological deterrent than a legal one". This may be particularly true in developing countries, where concerns about attracting investment are high, and the capacity to deal with disputes is low.

This section will explore these issues further in the context of a recent debate over mineral operations in Ghana's forest reserves. This case study is based on a variety of sources, including interviews I conducted in June 2005 under the condition of anonymity.

\subsection{Background}

Ghana has a very long history of mining, particularly of gold, dating back to preChristian times (Akabzaa, 2000, p. 8) and in the colonial period was known as 'The Gold Coast'. According to Akabzaa and Darimani (2001, p. 17), in the period following independence "generally, the vicissitudes in Ghana's mineral industry mirror trends in the global mineral industry". In the 1970s the mining industry was the second largest foreign exchange earner for Ghana and provided jobs for thousands of people in the rural areas. However, the state-owned mining enterprises 
were under-capitalised and the industry was facing collapse. ${ }^{17}$ From 1960 through to 1980 , various modifications were made to the mining code aimed at attracting private participation in the industry, "but these were quite cosmetic" (Akabzaa \& Darimani, 2001, p. 18) and for four decades (up to the 1980s) no new mine was opened in Ghana due to a "myriad of problems faced by mining investors and potential investors alike as a result of the economic, financial, institutional and legal framework within which the sector operated"18.

As in other African countries, deregulation of the mining sector in Ghana began in the context of a Structural Adjustment Programme. Reforms in Ghana are regarded as typifying the first phase of mining sector reforms undertaken in the context of these programmes (UNCTAD, 2005a, p. 41). The mining sector received priority attention under the country's Economic Recovery Programme initiated in 1983, as this sector was considered key to the country's economic revival (Campbell, 2004, p. 11). The World Bank carried out two major projects in the sector: first the Mining Sector Rehabilitation project, approved in 1988; followed in 1995 by the Mining Sector Development and Environment Project. A new Minerals and Mining Law was put into place in 1986, and a Minerals Commission was developed. The fiscal component of the laws was considered to be one of the most liberal at the time, only surpassed by those of Papua New Guinea (Campbell, 2004, p. 11). The newly formed Minerals Commission was charged with implementing the law as well as overall responsibility for advising the government on mineral policy, reviewing mining sector activities and serving as a one-stop shop for mineral investors.

According to a study by UNCTAD (2005a), investment in mining in Africa has increased considerably in the past two decades and the region is now ranked third behind Latin America and Oceania. According to UNCTAD (2005a, p. 39), this increase "can be attributed in part to major changes in mining codes that have helped orchestrate a state withdrawal from the sector, expanded opportunities for the private sector and increased incentives to attract FDI'. In Ghana, since the inception of the Economic Recovery Programme the industry has seen phenomenal growth. Over the period 1983-1998 some US\$4 billion of private investment capital went into mineral exploration, the establishment of new mines, and the rehabilitation of existing ones. ${ }^{19}$ Gold has been particularly important; Ghana is now the second largest producer of gold in Africa (after South Africa), and gold has replaced cocoa as the leading foreign exchange earner (Awudi, 2002, p. 1). However, a calculation by UNCTAD based on 2003 government figures showed that Ghana earned only about $5 \%$ of the total value of mineral exports-about US $\$ 46.7$ million out of a total value of US\$893.6 million (UNCTAD, 2005a, p. 50). Furthermore, according to Awudi (2002, p. 1) the increased activity in the sector has not led to a significant increase in employment.

\footnotetext{
${ }^{17}$ Letter from M. Karlsson, World Bank Country Director for Ghana, Sierra Leone and Liberia, to National Coalition of Civil Society Groups Against Mining in Ghana's Forest Reserves, December 4, 2003. Available online at: http://www.bicusa.org/bicusa/issues/Response_from_WBGhanaCountryDirector_12-04-03.pdf.

${ }^{18}$ Ghana Minerals Commission website: http://www.mincomgh.org/minerals_sector/index.html last viewed 06-07-06.

${ }^{19}$ Ibid.
} 


\subsection{Ghana's investment and mineral policy}

The 1986 Minerals and Mining Law provides for referral of disputes to arbitration in accordance with the UNCITRAL Rules, or within the framework of a bilateral agreement between Ghana and the investor's country. Ghana has so far concluded 21 BITs; some of the agreements have been ratified while others are still awaiting ratification. ${ }^{20}$ Ghana is also a signatory to the 1958 New York Convention.

The mining law recognises three stages of mineral development, and an investor requires a separate licence for each stage: reconnaissance (prospecting), prospecting (exploration) and mining (Omalu \& Wälde, 1998). In terms of mineral tenure, there is no automatic right for the holder of a reconnaissance licence to acquire a prospecting licence, however, there is an automatic right for the holder of a prospecting licence to obtain a mining lease (Addy, 1999, p. 237; Omalu \& Wälde, 1998). Mining leases are valid for up to 30 years, and generally include renewal clauses (Addy, 1999, p. 237). Negotiations for licences and leases are normally led by the Minerals Commission, and the constitution requires any contract or undertaking to be ratified in Parliament by a two-thirds voting majority. However, ratification has little impact on the substantive content of agreements (Ayine et al., 2005). According to Ayine et al. (2005, p. 3), “[w] hether and when contracts become available to the wider public depends on whether the Parliamentary Committee invites public comments on the contract document; for most agreements placed before Parliament this does not happen" and furthermore "a typical mining lease would likely bind the government to treat all information submitted under obligations in the lease as confidential for a period of five years, or until termination of the lease. Even then, the consent of the company might be required" (Ayine et al., 2005, p. 4).

In the course of my research, three mining leases ${ }^{21}$ have been obtained from company filings to the Security Exchange Commission in Washington, DC. ${ }^{22}$ These examples may give some insight into the substantive content of Ghanaian mining leases, however, it should be cautioned that other leases may differ significantly. Furthermore, it should be noted that in addition to mining leases, a more recent trend has been for companies to sign more general 'investment agreements' with the government. For example, Newmont Mining Corp. signed such an agreement in 2003

\footnotetext{
${ }^{20}$ According to the Government of Ghana website (http://www.ghana.gov.gh/faq/faqans.php?id=0000000022 last viewed 06-07-06) Ghana has negotiated BITs with Bulgaria, Burkina Faso, China, Cote d'Ivoire, Cuba, Denmark, Egypt, France, Germany, Guinea, Malaysia, Mauritania, Mauritius, Netherlands, Romania, South Africa, Switzerland, United Kingdom, United States of America (signed with OPIC), Yugoslavia, Zambia. The BITs with Denmark, the United Kingdom, The Republic of China, Romania and Switzerland have been ratified (according to the U.S. Department of State 2005 Investment Climate Statement for Ghana, see http://www.state.gov/e/eb/ ifd/2005/43028.htm). The U.S. has in fact signed three agreements with Ghana (the OPIC Investment Incentive Agreement, the Trade and Investment Framework Agreement, and the Open Skies Agreement), however these are not traditional BITs.

${ }^{21}$ Mining Lease signed between the Government of the Republic of Ghana and Canadian Bogosu Resources Ltd., 21 August 1987. Mining Lease signed between the Government of the Republic of Ghana and Canadian Bogosu Resources Ltd., 16 August 1988. Mining Lease signed between the Government of the Republic of Ghana and Bogoso Gold Ltd., 29 June 2001.

${ }^{22}$ All three leases are now under the control of Golden Star Resources Ltd. The 1987 and 1988 leases can be found in Golden Star Resources Ltd. Form 10-K (Annual Report) Filed 3/29/2006 For Period Ending 12/31/2005. The 2001 lease can be found in Golden Star Resources Ltd. Form 8-K Filed For Period Beginning 10/25/2001. These filings can be found online at http://www.edgar-online.com 
with the government that covered its investments under three mining leases. While I am currently unaware of the substantive content of this agreement, it has been reported in the media that it contains stability clauses. ${ }^{23}$ This trend is in line with the more recent changes proposed for Ghana's mining law, which will be discussed further in Sect. 4.4.

Returning to the content of the leases, it can be noted that with regard to environmental provisions, they are quite general:

The company shall adopt all necessary and practical precautionary measures to prevent undue pollution of rivers and other potable water and to ensure that such pollution does not cause harm or destruction to human or animal life or fresh water or vegetation (Article $8 \mathrm{~b}$ of all three leases).

In terms of dispute settlement, the 1987 and 1988 leases refer to the jurisdiction of ICSID for settlement by reconciliation or arbitration, while the more recent 2001 lease refers to UNCITRAL Rules (Article 35 of all three leases). All three leases also have a second section to the arbitration clause, which stipulates that:

The Parties acknowledge and agree that this Agreement was made on the basis of the laws and conditions prevailing at the date of the effective conclusion of the negotiation of this Agreement and accordingly, if thereafter, new laws and conditions come into existence which unfairly affect the interest of either party to this agreement, then the party so unfairly affected shall be entitled to request a re-negotiation and the parties shall thereupon re-negotiate. The parties hereby undertake and covenant with each other to make every effort to agree, cooperate, and negotiate and to take such action as may be necessary to remove the causes of unfairness or disputes.

This clause gives a preference to re-negotiation, but also clearly provides the investor with some stability.

\subsection{Mining in forest reserves}

Mining activities in Ghana are concentrated in the south of the country, as this is where the most substantial mineral deposits are found. Incidentally, this is also the area within which the majority of Ghana's remaining forestland is located. Following the launch of the Economic Recovery Programme, several gold mining companies were granted permission by the National Defense Council (NDC) government to carry out mineral exploration within forest reserves. Permanent forest estate, in the form of reserves, was developed by the colonial government in the early part of the last century, in recognition of the increasing pressures on Ghana's forests and with the intention to maintain climatic quality, protect watersheds and ensure an environment conducive to cocoa production (Kotey et al., 1998, p. 23). The demarcation of the forest estate was largely completed by 1939 . While it is widely acknowledged that much of the forest estate has been degraded despite the reserve status, it has also been suggested that without the reserves "Ghana wouldn't have any forest left", 24

\footnotetext{
${ }^{23}$ Newmont joins mining list" Ghana News Agency, 19 December 2003.

${ }^{24}$ Author's confidential interview with a non-governmental representative (\#3), Accra, June 2005.
} 
As early as 1992, the Forestry Commission was raising concerns about the potential impacts that mining could have on the reserves:

Mining in forest reserves will imply abandonment of scientific management of forest reserves and consequently loss of goods and services derived from our forest heritage set aside 60-70 years ago. Ghana could be sanctioned by the International Conservation organizations, which have credited Ghana with a long history of responsibility for tropical forest conservation and management (Tuffuor, 1992).

In 1996, based on the concerns about the depletion of the permanent forest estate and the potential for mineral activities to accelerate this depletion, the Ministry of Lands and Forestry placed a moratorium on mineral operations in forest reserves. ${ }^{25}$ However, by this time, some mining companies had already reached advanced stages of exploration. The government selected seventeen companies, apparently on the basis of the level of investment incurred and the state of exploration that had been achieved, and determined that they should be allowed to continue with their exploration activities. ${ }^{26}$ In 1997 the Operational Guidelines for Mineral Exploration in Forest Reserves for Selected Companies were produced and put in place to regulate exploration activities and the selected companies were invited to re-apply for Forest Entry Permits. $^{27}$

Up until this point, the issue had not been widely publicised, however in 1998 the non-governmental organisation Friends of the Earth (FOE) Ghana began to investigate further. The group visited the exploration sites and spoke with companies, who claimed that if they found economically viable deposits they would be given mineral leases. ${ }^{28}$ FOE-Ghana expressed alarm over the potential consequences for forest conservation and founded a Coalition of Civil Society Groups Against Mining in Ghana's Forest Reserves (hereafter referred to as the FOEGhana Coalition).

In response to the concerns that were increasingly being raised over the possibility of mining in forest reserves, and in preparation for the expected transition from exploration to mine development, the Ghana Chamber of Mines, an association of representatives of mining companies operating in Ghana, took a fact-finding mission to South Africa and Australia, bringing with them representatives of the Forestry Commission, Environmental Protection Agency and other institutions. The purpose of the trip was to view successful mining operations in forests in these countries. Upon return from the trip the Chamber commissioned the preparation of the Environmental Guidelines for Mining in Productive Forest Reserves. In one view the issuing of the Environmental Guidelines followed "a thorough analysis and debates involving all stakeholders

\footnotetext{
${ }^{25}$ Newmont Ghana Gold Ltd. 2005. Environmental and Social Impact Assessment: Ahafo South Project. Accra. Available online at: http://www.newmont.com/en/operations/projectpipeline/ahafo/ docs/envsocimpaccess.asp

${ }^{26}$ Chirano Gold Mines Ltd. 2003. Chirano Gold Project Scoping Report \& Terms of Reference. Prepared by SGS Environment, Project No. B246. Available in the Environmental Protection Agency Library, Accra.

${ }^{27}$ Environmental Guidelines for Mining in Productive Forest Reserves in Ghana, May 2001, p. 1.

${ }^{28}$ Author's confidential interview with a non-governmental representative (\#3), Accra, June 2005.

算 Springer
} 
over a period of approximately 2.5 years" and they were provided in "a format acceptable to the various interested parties and stakeholders". ${ }^{29}$ However, members of the FOE-Ghana Coalition took a quite different view, pointing out that there was no consultation with communities directly affected by mining or forestry, or from civil society organisations. ${ }^{30}$ The Environmental Guidelines listed twelve organisations as key contributors, ${ }^{31}$ all of which are either representatives of the mining industry or government agencies, and furthermore, the funding for the project came entirely from foreign mining companies leading one observer to conclude: "the production of the document was funded by the mining industry and it cannot be trusted since it merely parrots the wishes of the mining industry". 32 In any event, the guidelines are non-binding, and provisions are frequently qualified by language such as "where practicable".

By the time the Environmental Guidelines had been published in 2001, a new government under the New Patriotic Party (NPP) had been elected, and had thus "inherited the problem". ${ }^{33}$ Under increasing public pressure, the list of proposed operations was decreased to five ${ }^{34}$ and the government undertook site visits. The final approval for these operations came on 12 February 2003, in a letter issued by the Ministry of Mines to the Ghana Chamber of Mines. ${ }^{35}$

The Ministry of Mines (now Ministry of Lands, Forestry and Mines) has defended its decision to allow mining in forest reserves with several key arguments: ${ }^{36}$

- The companies had invested substantial sums of money: not allowing them to proceed would mean that Ghana would have to compensate them and would also discourage future investments in the industry;

- The benefits of mining in terms of jobs and local infrastructure and royalties to the government outweigh the environmental consequences;

- The areas earmarked for mining are not pristine, they have already been degraded; and

\footnotetext{
${ }^{29}$ Chirano Gold Mines Ltd. 2003. See footnote 26.

${ }^{30}$ National Coalition of Civil Society Groups Against Mining in Ghana's Forest Reserves: A presentation to the Ghanaian Media, 31 March 2004, Old Press Centre, Accra. Available online at: http://www.bicusa.org/bicusa/issues/Coalition_press_statement_March04.pdf.

${ }^{31}$ Abosso Goldfields Ltd. (South Africa), Ashanti Goldfields Company Ltd. (South Africa), Birim Goldfields Inc. (Canada), Environmental Protection Agency, Forestry Commission, Forestry Services Division, Ghana Chamber of Mines, Knight Piesold Consulting (global consulting firm, with representatives from Australia and South Africa), Minerals Commission, Mines Department, Ministry of Lands and Forestry, Wildlife Division.

32، Golden Greed: Trouble Looms over Ghana's Forest Reserves”, World Rainforest Movement News Release. Available online at: http://www.wrm.org.uy/countries/Ghana/Goldengreed.html, last viewed 06-07-06.

${ }^{33} \mathrm{Mr}$. Kwadjo Adjei Darko, former Minister of Mines, quoted in ibid.

${ }^{34}$ The companies were Newmont (United States), Nevsun Resources (Canada), Birim Goldfields (acquired by Goldenstar Resources/Canada), Chirano Goldmines (acquired by Redback Mining/ Canada), and Satellite Goldfields (acquired by Goldenstar Resources/Canada).

${ }^{35}$ Chirano Gold Mines Ltd. 2003. See footnote 26.

${ }^{36}$ This summary of arguments is based on Tetteh (2004), various news articles quoted elsewhere in this paper, and the author's confidential interviews with mining investors (\#1 \& \#20), government officials (\#2 \& \#12), non-governmental representatives (\#3, \#4, \#8 \& \#11), representatives of international organisations (\#6), and academics (\#9, \& \#18), Accra, Kumasi and New Abirim, June 2005.
} 
- Stricter environmental controls will be placed on the companies (the Environmental Guidelines) and they will be required to plant trees outside of their concessions in addition to rehabilitating the mine area.

On the other hand the FOE-Ghana Coalition argued that: ${ }^{37}$

- The net return of mineral wealth despite the significant foreign investment inflow into the sector is very doubtful;

- Forest reserves must be protected for their own sake because of the vital economic, social and environmental functions they play which is necessary for the quality of life we live on Earth;

- Mining in forest reserves contravenes various national policies and the principles underlining the establishment of forest reserves in Ghana; and

- Mining in forest reserves contravenes international agreements to which Ghana is signatory, such as the Convention to Combat Desertification, the Conservation on Biological Diversity, and the Kyoto Protocol.

According to several sources in Ghana, the threat of international investment arbitration was clearly made by companies with interests in the forest reserves, though there is disagreement from the sources over whether this was a serious threat, ${ }^{38}$ or merely an excuse used by the government to defend its position. ${ }^{39}$ The main companies involved in the dispute were based in Canada, the United States and South Africa. Canada does not have a BIT with Ghana, there is no record of a South African BIT ever having been ratified, and the American agreements (a framework Agreement Concerning the Development of Trade and Investment Relations and an Investment Incentive Agreement) do not provide for investor-state dispute settlement. Therefore, it is unlikely that any of the companies could have brought a dispute based on a claim of expropriation under an international agreement. Furthermore, the companies did not have mineral leases, which would have provided some level of stability. However, security of mineral tenure in Ghana, as mentioned above, ensures that holders of a prospecting licence have a right to acquire a mineral lease for minerals that they discover in the area covered by the licence. This would have thus been the mostly likely basis for a dispute.

One publication in Ghana argued that "it is better for the government to refund the money to the companies, rather than giving out concessions for them to destroy the remaining forest reserves in the name of investment", ${ }^{40}$ however, others suggest that the government simply could not afford to do so. ${ }^{41}$ Potentially even more crucial than concerns over compensation payments were apprehensions about the impact that the dispute would have on the image of the country in the eyes of investors in both the mineral and other sectors. Several observers suggested that the government feared arbitration not because they feared losing, but because they feared the impact that denying the leases and proceeding to arbitration would have on their reputation

\footnotetext{
${ }^{37}$ National Coalition of Civil Society Groups Against Mining in Ghana's Forest Reserves. See footnote 30 .

${ }^{38}$ Author's confidential interviews with government officials (\#7), academics (\#9), and non-governmental representatives (\#11), Accra, June 2005.

${ }^{39}$ Author's confidential interviews with non-governmental representatives (\#8), and academics (\#9 \& \#18), Accra and Kumasi, June 2005.

40“"Whither the Mining Industry?" Public Agenda, 12 May 2003.

${ }^{41}$ Author's confidential interviews with government officials (\#7), and academics (\#9), Accra, June 2005.

笔 Springer
} 
as an investor-friendly country. ${ }^{42}$ It has even been suggested that the indecision over whether to open the forest reserves to mining contributed to dwindling investment in the country. ${ }^{43}$ In addition, at least one company seeking a concession inside a reserve made it clear that its other potential investments in the country would be impacted by the government's decision. ${ }^{44}$

The other arguments made in favour of allowing the mining to go ahead include the claims that other activities (e.g. illegal logging) contribute more to forest loss and that, in any case, the forest reserves have already been degraded. According to one publication "Ghana mine operators roll their eyes at the 'reserve' designations because locals have already plundered them". ${ }^{45}$ Even the former Minister of Mines Cecilia Bannerman has reportedly stated that "many of these reserves are reserves only on paper",46 and the current Minister of Lands, Forestry and Mines, Prof. Dominic Fobih, has also referred to the forests as "so-called reserves". ${ }^{47}$ Others take a different view; disputing first of all the notion that the reserves in question are all degraded and suggesting to the contrary that there are still areas of virgin forest. ${ }^{48}$ In addition it has also been suggested that it is illogical to conclude that because an area is degraded it should be "offered up for further degradation". ${ }^{49}$ Even a representative of one of the mining companies involved in the debate admitted that it was understandable that there was controversy over mining, even if the forests were degraded, because there was not much forest left in Ghana. ${ }^{50}$

In the end, the government's compromise between the position of the investors/ Minerals Commission and that of the environmentalists/Forestry Commission was to restrict the number of companies allowed to operate in the forest reserves and to tighten the environmental requirements of those companies. The companies operating in forest reserves will not be permitted to build any additional facilities within the reserves and will also be required to reforest the areas that they clear. However, according to one forestry official, the idea of restoring the forest is a myth: "You fell tropical trees and in place you plant grass and ornamental trees-you fell mahogany and plant cassia-it is not the same. After mining the soil is unable to sustain indigenous species". 51 Officials from international organisations operating in Ghana were even more pessimistic; "Resources from mining will never be reinvested in forestry; rehabilitation doesn't happen in Africa". 52

\footnotetext{
${ }^{42}$ Author's confidential interviews with non-governmental representatives (\#4), representatives of international organisations (\#6), government officials (\#13), and academics (\#18), Accra and Kumasi, June 2005.

43،"Ghana lures miners with new laws opening forests" Reuters, 20 February 2003.

${ }^{44}$ When Newmont found gold in two locations, one inside a reserve, it was reported that the company "wants both concessions or nothing". See "Ghana's Gold Dilemma" BBC News, 4 February 2003.

"45"Country Winds up for Enviro-Mining Clash” Mineweb, 4 September 2003.

${ }^{46}$ Ibid.

47،"Minister Rekindles Mining in Forest Reserve Controversy” Public Agenda, 8 September 2003.

${ }^{48}$ Author's confidential interviews with government officials (\#2) and non-governmental representatives (\#3, \#4, \#8, \& \#11) Accra, June 2005.

${ }^{49}$ Author's confidential interview with a non-governmental representative (\#11) Accra, June 2005.

${ }^{50}$ Author's confidential interview with a mining investor (\#20), New Abirim, June 2005.

${ }^{51}$ Author's confidential interview with a government official (\#13) Accra, June 2005.

${ }^{52}$ Author's confidential interview with a representative of an international organisation (\#14) Accra, June 2005.
} 
4.4 Epilogue: the future of mineral investment in Ghana

It has been noted above that, when it was drafted, the 1986 Minerals and Mining Law was considered very attractive for investors; however, times change. At the time of writing, the Government of Ghana was in the process of drafting a new mining law aimed at making the country more competitive vis-à-vis other regimes (UNCTAD, 2003, p. 42). Draft legislation was submitted to Parliament in mid-2002 but was withdrawn and resubmitted several times. In a draft of June $2005,{ }^{53}$ it was clear that there were clauses which could have implications for the regulation of the environment. The key provisions are found in Sections 45 and 46, where investors are given the opportunity to sign so-called 'stability agreements' and 'development agreements' with the government. These agreements are binding and are subject to international arbitration. A stability agreement ensures:

that the holder of the mining lease will not, for a period not exceeding fifteen years from the date of the agreement;

a. be adversely affected by any new enactment, orders, instruments or other actions made under a new enactment or changes to any enactment, orders, instruments that existed at the time of the stability agreement, or other actions taken under these that have the effect or purports to have the effect of imposing obligations upon the holder or applicant of the mining lease;

\section{(Section 45)}

According to the Minister of Lands, Forestry and Mines, Prof. Dominic Fobih, the "essence" of this provision is to "protect the holder of a mining lease for a period not exceeding fifteen years from being adversely affected by future changes in laws that result in heavier financial burdens being imposed on the holder". 54 In addition to the stability agreement, an investor may also enter into a development agreement, if the proposed investment will exceed US\$500 million. Such an agreement "may contain provisions";

a) relating to the mineral right or operations to be conducted under the mining lease;

b) relating to the circumstance or manner in which the Minister or the Commission will exercise a discretion conferred by or under this Act;

c) on stability terms as provided under Section 45

d) relating to environmental issues and obligations of the holder to safeguard the environment in accordance with this Act or other enactment; and

e) dealing with the settlement of disputes

(Section 46, emphasis added)

Butler (2004, pp. 74-75) has described similar clauses found in Tanzania's 1998 Mining Act as a "legislative loophole", which "allows some rules to be suspended or modified in favour of private corporate mining interests". The former Minister of Mines in Ghana viewed it quite differently, stating: "Such agreements are mutually beneficial to investors and government as they enable both parties to negotiate and

\footnotetext{
${ }^{53}$ A copy was obtained from the World Bank Office in Accra.

${ }^{54}$ Memorandum to the Draft Minerals and Mining Bill, dated 17 May 2005.

Springer
} 
agree on specified commitments and expectations". 55 The Ghana National Coalition on Mining (a group of organisations, communities, and individuals) is not convinced of this and is strongly opposed to the inclusion of stability or development agreements in the new Bill. ${ }^{56}$

\section{Conclusions}

There is no question that mining is a risky activity, both from an economic and an environmental standpoint. It is understandable, therefore, that mineral investors have sought to reduce the risks that they face by gaining legal protection for their investments, while governments have sought to reduce environmental risks by regulating the sector. The question is whether, in the struggle to compete for a limited share of foreign investment, developing countries have been able to achieve a balance between these competing interests, or on the other hand, whether too great a burden of risk has been shifted to regulators, and to the broader public. Arguably, in Ghana an appropriate balance between the protection of investment and protection of the environment has not been struck. In fact, both the outcome of the debate over mining in forest reserves and the provisions in the draft mining bill suggest a worrying trend.

The Ghanaian case provides several lessons for researchers exploring the relationship between investment and the environment. First, while the literature on this topic has been largely focused on developed countries, both in terms of the focus on industrial flight in the pollution haven debate, and in terms of the focus on NAFTA disputes in the legal field, the Ghanaian case shows that there is ample reason to devote more effort to studying this relationship in the specific context of developing countries. Such research is critical as foreign investment becomes ever more important to the developing world, and as the rapid rise in agreements on investment continues.

Second, the case illustrates how competition for investment and legal protection of investment are intimately connected in a reinforcing relationship; governments offer legal protections in order to compete for investment, and may in turn also try to avoid investment arbitration in order to maintain their competitiveness. Thus, it illustrates the limits of discussions, such as those surrounding the pollution haven hypothesis and investor-state disputes, which fall along disciplinary lines.

Third, the Ghana case shows that in addition to international agreements (which have recently been placed under the spotlight by non-governmental organisations) national laws and state contracts also offer protections for investment which may mirror those protections found in BITs, or even surpass them. Stability clauses or agreements, in particular, have the potential to greatly influence the development of environmental law in countries where they are employed. This is especially true in the context of the mineral sector, where investments are generally long-term, with contracts that can last thirty years or more.

\footnotetext{
${ }^{55}$ Speech by Cecilia Bannerman, Ghana Minister of Mines, at the Conference of Montreal's CIDA/ IDRC International Forum Bringing the Best of the Private Sector to Development, 7 June 2004. Available online at http://www.idrc.ca/en/ev-61467-201-1-DO_TOPIC.html.

${ }^{56}$ Memorandum on the Minerals and Mining Bill 2005 Submitted by the National Coalition on Mining (NCOM) to the Select Parliamentary Committee on Mines and Minerals, 8 June 2005.
} 
Finally, it would appear that the concept of regulatory chill is one which deserves further consideration, as it appears to encapsulate all of the nuances of the Ghanaian case. The Government of Ghana clearly believed that it risked losing investment if it did not allow mining to proceed in the forest reserves. It also may have believed that it would have had to compensate the companies involved. Thus the chilling effect is found both in the threat of lost investment and the threat of arbitration. It is of course not possible to draw far-reaching conclusions about the relevance of the regulatory chill hypothesis to the entire developing world from one example in one country. However, it is fair to suggest that it is an area of research that warrants further inquiry. While such inquiry will undoubtedly prove difficult, it is essential to the development of a comprehensive understanding of the relationship between investment and the environment, which in turn, is critical for any project that aims to make investment sustainable.

\section{References}

Addy, S. N. (1999). Ghana: Revival of the mineral sector. Resources Policy, 24(4), 229-239.

Akabzaa, T. (2000). Boom and dislocation: The environmental and social impacts of mining in the Wassa West District of Ghana. Accra: Third World Network Africa.

Akabzaa, T., \& Darimani, A. (2001). Impacts of mining sector investment in Ghana: A study of the Tarkwa mining region. Prepared for the World Bank Structural Adjustment Participatory Review Initiative (SAPRI).

Ayine, D., Blanco, H., Cotula, L., Djire, M., Kotey, N. A., Khan, S. R., Reyes, B., Ward, H., \& Yusuf, M. (2005). Lifting the lid on foreign investment contracts: The real deal for sustainable development. London: International Institute for Environment and Development.

Awudi, G. B. K. (2002). The role of foreign direct investment (FDI) in the mining sector of Ghana and the environment. Paper Presented at the Conference on Foreign Direct Investment and the Environment, OECD, Paris.

Barberis, D. (1998). Negotiating mining agreements: Past, present and future trends. The Hague: Kluwer Law International.

Bastida, E. (2001). A review of the concept of security of mineral tenure: Issues and challenges. Journal of Energy \& Natural Resources Law, 19(1), 31-43.

Bernardini, P. (2001). Investment protection under bilateral investment treaties and investment contracts. Journal of World Investment, 2(2), 235-247.

Baughen, S. (2001). Investor rights and environmental obligations: Reconciling the irreconcilable? Journal of Environmental Law, 13(2), 199-220.

Blackaby, N. (2004). Public interest and investment treaty arbitration. Transnational Dispute Management, 1(1) (www.transnational-dispute-management.com).

Brunnermeier, S. B., \& Levinson, A. (2004). Examining the evidence on environmental regulations and industry location. Journal of Environment and Development, 13(1), 6-41.

Butler, P. (2004). Liberalisation of investment and the mining sector: Analysis of the content and certain implications of the Tanzania 1998 mining act. In B. Campbell (Ed.), Regulating mining in Africa: For whose benefit? (pp. 67-80). Uppsala: Nordiska Afrikainstitutet.

Campbell, B. (2004). Introduction. In B. Campbell (Ed.), Regulating mining in Africa: For whose benefit? (pp. 7-24). Uppsala: Nordiska Afrikainstitutet.

Caspary, G., \& Berghaus, S. (2004). The changing nature of foreign direct investment in developing countries: Evidence and implications. Journal of World Investment and Trade, 5(4), 683-704.

Chudnovsky, D., \& López, A. (2002). Globalization, foreign direct investment and sustainable human development. In K. Gallagher \& J. Werksman (Eds.), The Earthscan reader on international trade and sustainable development (pp. 45-76). London: Earthscan.

Clapp, J. (2002). What the pollution havens debate overlooks. Global Environmental Politics, 2(2), $11-19$.

Cohen, M. (1996). A new menu for the hard-rock cafe: International mining ventures and environmental cooperation in developing countries. Stanford Environmental Law Journal, 15, $130-186$. 
Dalupan, M. C. G. (2005). Mining and sustainable development: Insights from international law. In E. Bastida, T. Wälde, \& J. Warden-Fernández (Eds.), International and comparative mineral law and policy: Trends and prospects (pp.149-170). The Hague: Kluwer Law International.

de Sa, P. (2005). Mineral policy: A world bank perspective. In E. Bastida, T. Wälde, \& J. WardenFernández (Eds.), International and comparative mineral law and policy: Trends and prospects (pp.493-504). The Hague: Kluwer Law International.

Esty, D. C., \& Geradin, D. (1998). Environmental protection and international competitiveness: A conceptual framework. Journal of World Trade, 32(3), 5-46.

Fortier, L. Y., \& Drymer, S. L. (2004). Indirect expropriation in the law of international investment: I know it when I see it, or caveat investor. ICSID Review: Foreign Investment Law Journal, 19(2), 293-327.

Gantz, D. A. (2001). Potential conflicts between investor rights and environmental regulation under NAFTA's Chapter 11. George Washington International Law Review, 33(3/4), 651-752.

Garcia, C. G. (2004). All the other dirty little secrets: Investment treaties, Latin America, and the necessary evil of investor-state arbitration. Florida Journal of International Law, 16, 301-369.

Gray, K. R. (2002). Foreign direct investment and environmental impacts - Is the debate over? RECIEL, 11(3), 306-313.

Guzman, A. T. (1998). Why LDCs sign treaties that hurt them: Explaining the popularity of bilateral investment treaties. Virginia Journal of International Law, 38, 639-688.

Hallward-Driemeier, M. (2003). Do bilateral investment treaties attract FDI? Only a bit...and they could bite. Policy Research Working Paper 3121, Washington, DC: World Bank.

Kotey, N. A., Francois, J., Owusu, J. G. K., Yeboah, R., Amanor, K. S., \& Antwi, L. (1998). Falling into place. Policy that works for forests and people series. No.4. London: International Institute for Environment and Development.

Mabey, N., \& McNally, R. (1999). Foreign direct investment and the environment. Godalming, Surrey: WWF-UK.

Mann, H. (2001). Private rights, public problems: A guide to NAFTA's controversial chapter on investor rights. Winnipeg: International Institute for Sustainable Development/World Wildlife Fund.

von Moltke, K. (2002). International investment and sustainability: Options for regime formation. In K. Gallagher \& J. Werksman (Eds.), The Earthscan reader on international trade and sustainable development (pp. 347-369). London: Earthscan.

von Moltke, K., \& Mann, H. (2004). Towards a southern agenda on international investment: Discussion paper on the role of international investment agreements. Winnipeg: International Institute for Sustainable Development.

Neumayer, E. (2001a). Greening trade and investment: Environmental protection without protectionism. London: Earthscan.

Neumayer, E. (2001b). Do countries fail to raise environmental standards? An evaluation of policy options addressing "regulatory chill". International Journal of Sustainable Development, 4(3), 231-244 (revised version obtained from author, pp. 1-27).

Omalu, M. K., \& Wälde, T. (1998). Key issues of mining law: A brief comparative survey as a background study for the reform of mining law. CEPMLP Internet Journal, 3(13) (www.dundee.ac.uk/cepmlp/journal/).

Oman, C. (2000). Policy competition for foreign direct investment: A study of competition among governments to attract FDI. Paris: OECD.

Onwuekwe, C. B. (2006). Reconciling the scramble for foreign direct investments and environmental prudence: A developing country's nightmare.Journal of World Investment and Trade, 7(1), 113-141.

Otto, J. (1994). The international competition for mineral investment: Implications for Asia-Pacific. Centre for Petroleum and Mineral Law and Policy Seminar Paper No.Sp15. Dundee: Centre for Petroleum and Mineral Law and Policy.

Otto, J., \& Cordes, J. (2002). The regulation of mineral enterprises: A global perspective on economics, law and policy. Westminster, Colorado: Rocky Mountain Mineral Law Foundation.

Peter, W. (1995). Arbitration and renegotiation of international investment agreements (2nd ed.). Dordrecht: Kluwer Law International.

Peterson, L. E. (2003). Emerging bilateral investment treaty arbitration and sustainable development. Winnipeg: International Institute for Sustainable Development.

Peterson, L. E. (2005). All roads lead out of Rome: Divergent paths of dispute settlement in bilateral investment treaties. In L. Zarsky (Ed.), International investment for sustainable development: Balancing rights and rewards (pp.123-149). London: Earthscan. 
Pring, G., \& Siegele, L. (2005). International law and mineral resources development. In E. Bastida, T. Wälde, \& J. Warden-Fernández (Eds.), International and comparative mineral law and policy: Trends and prospects (pp.127-148). The Hague: Kluwer Law International.

Pritchard, R. (2005). Safeguards for foreign investment in mining. In E. Bastida, T. Wälde, \& J. Warden-Fernández (Eds.), International and comparative mineral law and policy: Trends and prospects (pp.73-98). The Hague: Kluwer Law International.

Sandbroke, R., \& Mehta, P. (2002). Rapporteurs report from the OECD Global Forum on International Investment Conference "FDI and Environment - Lessons from the Mining Sector". Paris: OECD.

Soloway, J. A. (2002). Environmental expropriation under NAFTA Chapter 11: The phantom menace. In J. Kirton \& V. W. MacLaren (Eds.), Linking trade, environment, and social cohesion: NAFTA experiences, global challenges (pp. 131-44). Aldershot: Ashgate.

Sornarajah, M. (2004). The international law on foreign investment (2nd ed.). Cambridge: Cambridge University Press.

Sornarajah, M. (2002). A developing country perspective of international economic law in the context of dispute settlement. In A. H. Qureshi (Ed.), Perspectives in international economic law (pp. 83-110). The Hague: Kluwer Law International.

Strohm, L. A. (2002). Pollution havens and the transfer of environmental risk. Global Environmental Politics, 2(2), 29-36.

Tetteh, F. (2004). Mining in the forest reserve. Journal of Energy and Natural Resources Law, 22(2), 241-242.

Tuffuor, K. (1992). Statement on mining and degradation of forest reserves in Ghana. In P. C. Acquah (Ed.), Proceedings from the national seminar on the environmental guidelines to regulate mining activities in Ghana. Accra: Minerals Commission.

UNCTAD. (2005a). Economic development in Africa: Rethinking the role of foreign direct investment, UNCTAD/GDS/AFRICA/2005/1. Geneva: United Nations.

UNCTAD. (2005b). Investor-state disputes and policy implications. Trade and Development Board: Commission on Investment, Technology and Related Financial Issues, Ninth Session 7-11 March 2005, TD/B/COM.2/62. Geneva: United Nations.

UNCTAD. (2005c). Latest developments in investor-state dispute settlement. IIA Monitor No. 4. UNCTAD/WEB/ITE/IIT/2005/2. Geneva: United Nations.

UNCTAD. (2005d). Recent developments in international investment agreements. IIA Monitor No. 2. UNCTAD/WEB/ITE/IIT/2005/1. Geneva: United Nations.

UNCTAD. (2004). State contracts. Issues in International Investment Agreements, UNCTAD/ITE/ IIT/2004/11. Geneva: United Nations.

UNCTAD. (2003). Investment policy review: Ghana, UNCTAD/ITE/IPC/Misc.14/Rev.1. Geneva: United Nations.

UNCTAD. (2000). Taking of property. Issues in International Investment Agreements, UNCTAD/ ITE/IIT/15. Geneva: United Nations.

UNCTAD. (1997). Management of commodity resources in the context of sustainable development: Governance issues for the mineral sector, UNCTAD/ITCD/COM/3. Geneva: United Nations.

Verhoosel, G. (1998). Foreign direct investment and legal constraints on domestic environmental policies: Striking a "reasonable" balance between stability and change. Law and Policy in International Business, 29(4), 451-479.

Wälde, T., \& N'Di, G. (1996). Stabilising international investment commitments: International law versus contract interpretation. CEPMLP Internet Journal, 1 (www.dundee.ac.uk/cepmlp/ journal/).

Warhurst, A. (1994). Environmental degradation from mining and mineral processing in developing countries: Corporate responses and national policies. Paris: OECD.

Wheeler, D. (2002). Beyond pollution havens. Global Environmental Politics, 2(2), 2-10.

Williams, J. P. (2005). Legal reform in mining: Past, present, future. In E. Bastida, T. Wälde, \& J. Warden-Fernández (Eds.), International and comparative mineral law and policy: Trends and prospects (pp.37-72). The Hague: Kluwer Law International. 